\title{
COMPARISON OF VENTILATION RESPONSES TO HYPERCAPNIA AT NORMOTHERMIA AND HYPOTHERMIA DURING HALOTHANE ANAESTHESIA*
}

\author{
JoSEPH O. Sodipo, F.F.A.R.C.S. (ENG.) † AND Do CHIL LEE, M.D.
}

\begin{abstract}
VeNTILATION RESPONSES of animals to hypercapnia have been studied by several investigators with different results. Cranston and his co-workers ${ }^{1}$ compared the ventilation of anaesthetized normothermic and hypothermic dogs during inhalation of 6 per cent carbon dioxide in air and concluded that during hypothermia the response was not different from that observed during normothermia. Salzano and Hall, ${ }^{2}$ on the other hand, reported (in dogs anaesthetized with dial) a markedly depressed slope in the ventilation response at $29^{\circ} \mathrm{C}$ to inhalation of 4 per cent and 5.5 per cent carbon dioxide in air. Regan and Eger ${ }^{3}$ confirmed Salzano's data during their study using constant-depth halothane anaesthesia. In none of the previous studies were respiratory effects of hypercapnia investigated at lower temperatures.

In the present study, observations were made at $37^{\circ} \mathrm{C}, 28^{\circ} \mathrm{C}$, and $25^{\circ} \mathrm{C}$ and the levels of respired carbon dioxide were 10 per cent and 15 per cent at which some reversal of carbon dioxide response was evident.
\end{abstract}

\section{METHOD}

Five unpremedicated mongrel dogs weighing 10 to $16 \mathrm{~kg}$ were studied. Anaesthesia was induced with thiopental sodium $15 \mathrm{mg} / \mathrm{kg}$. After intubation, anaesthesia was maintained by a high flow technique with halothane from a copper kettle vaporizer and mixture of approximately 50 per cent oxygen in air, so that the $\mathrm{PaO}_{2}$ tension was maintained above $250 \mathrm{~mm}$ of mercury. Animals breathed spontaneously throughout the experiments.

End-tidal carbon dioxide concentration was continually monitored with a Godart infra-red analyzer. Femoral artery and vein were cannulated. Arterial blood samples were taken for measurement of $\mathrm{pH}, \mathrm{PacO}_{2}$, and $\mathrm{PaO}_{2}$ and correction factors applied. ${ }^{8,9}$ Blood halothane level was measured by gas chromatographic technique after extraction with heptane. Range was $20 \pm 2 \mathrm{mg} / 100 \mathrm{mls}$.

Expired gas volume was measured with a continuous flow spirometry technique (Figure 1) described by Nunn ${ }^{5}$ as well as others. ${ }^{6}$

Volumes were converted to conditions of ambient pressure, body temperature and saturated water vapor (BTPS). ${ }^{7}$ Oesophageal temperature was continuously

"From the Department of Anaesthesia, University of Toronto.

Presented at 3rd European Congress of Anaesthesiologists, Prague, September 1970.

†Present address Department of Anaesthesia, College of Medicine, University of Lagos, Lagos, Nigeria. 


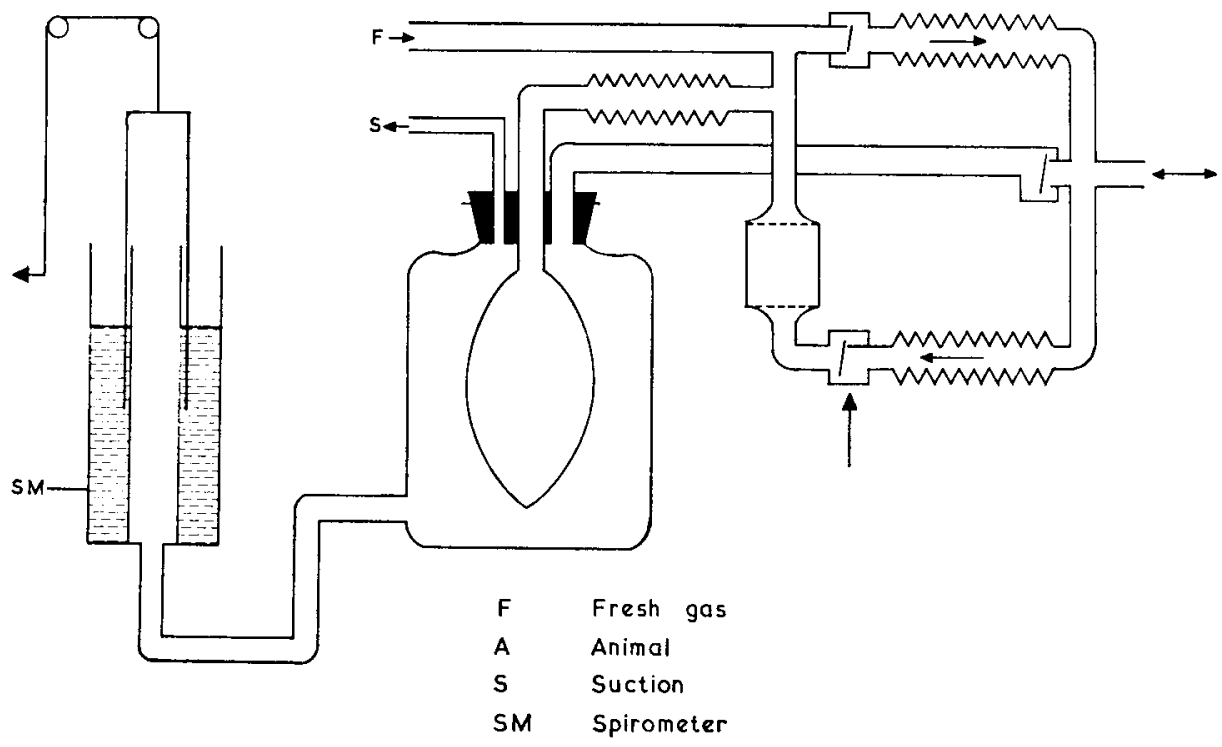

Figure 1

measured with a thermistor-probe electrode and Yellow Springs telethermometer.

Response to hypercapnia was recorded at two levels of 10 per cent and 15 per cent increased carbon dioxide. After a period of steady-state the resting ventilation was recorded, correlated with a sample of arterial blood for $\mathrm{pH}, \mathrm{PaCO}_{2}$, and $\mathrm{PaO}_{2}$. Inspired carbon dioxide tension was then increased by removing the carbon dioxide absorber and by adding the desired percentage of carbon dioxide. The endtidal carbon dioxide tension was maintained constantly for at least 15 minutes. Arterial blood was withdrawn during the last minute of ventilation at this arterial carbon dioxide tension $\left(\mathrm{PaCO}_{2}\right)$, and minute ventilation (ve) again recorded. This was then repeated at each new level of carbon dioxide.

The ventilation response to carbon dioxide was repeated at two levels of hypothermia, $28^{\circ} \mathrm{C}$, and $25.3^{\circ} \mathrm{C}$. Hypothermia was induced by surface cooling with ice. Observations were made after 15 minutes stabilization at the desired temperature. The animals were rewarmed and further observations recorded on return to $28^{\circ} \mathrm{C}$ and $37^{\circ} \mathrm{C}$.

\section{RESULTS}

Table I summarizes the results. Resting minute ventilation (VE) fell progressively from 3.02 litres per minute at $37^{\circ} \mathrm{C}$ to 1.7 litres per minute at $28^{\circ} \mathrm{C}$ and to 1.32 litres per minute at $25.3^{\circ} \mathrm{C}$ and rose to 2.5 litres per minute on rewarming to $37^{\circ} \mathrm{C}$. It is also interesting to note that despite the decrease of ventilation at $28^{\circ} \mathrm{C}$ 
SUMMARY OF RESULTS (TABLE I)

VENTILATORY RESPONSE TO $\mathrm{CO}_{2}(10 \%$ and $15 \%)$ DURING NORMOTHERMIA AND HYPOTHERMIA IN 5 DOGS

Mean $=$ Standard Deviation

\begin{tabular}{|c|c|c|c|c|c|}
\hline & \multicolumn{5}{|c|}{ TEMPERATURE $0^{C}$} \\
\hline & $37 \pm 0.5$ & $28 \pm 0.4$ & $25.3 \pm 0.2$ & $28 \pm 0.2$ & $37 \pm 0.5$ \\
\hline Resting VE (L/m.) & $3.02 \pm 0.26$ & $1.7 \pm 0.29$ & $1.32 \pm 0.08$ & $2.4 \pm 0.3$ & $2.5 \div 0.21$ \\
\hline Resting $\mathrm{PaCO}_{2}$ (mm. $\mathrm{Hg}$.) & $39.9 \pm 0.89$ & $30.8 \pm 1.6$ & $31,2 \pm 2.2$ & $32.5 \pm 1.72$ & $41.5 \pm 1.5$ \\
\hline Resting pH (units) & $7.335 \div 0.02$ & $7.42 \pm 0.01$ & $1.41 \pm 0.05$ & $7.415 \pm 0.02$ & $7.33 \pm 0.03$ \\
\hline Base Excess ( $m E q / L)$ & $-4.4 \pm 0.8$ & $-3.76 \pm 0.97$ & $-3.3 \pm 2.7$ & $-3.5 \pm 1.7$ & $-4.6 \pm 1.1$ \\
\hline $\begin{array}{l}\text { Mean } \mathrm{CO}_{2} \text { response slope } \\
(\mathrm{L} / \mathrm{min} / \mathrm{mm} . \mathrm{Hg} .)\end{array}$ & $0.23 \pm-0.04$ & $0.045 \pm 0.01$ & $0.022 \pm 0.01$ & $0.061 \pm 0.02$ & $0.24 \pm 0.04$ \\
\hline
\end{tabular}

CHANGES IN VENTILATORY RESPONSES

TO HYPERCAPNIA DURING COOLING

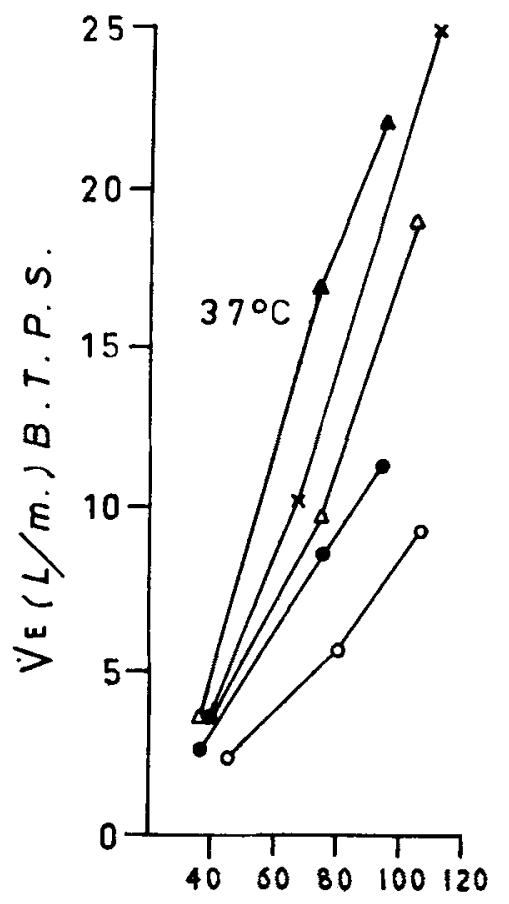

$\times \operatorname{Dog} 1$

- $\operatorname{Dog} 2$

- $\operatorname{Dog} 3$

$\triangle \operatorname{Dog} 4$

$\triangle \operatorname{Dog} 5$
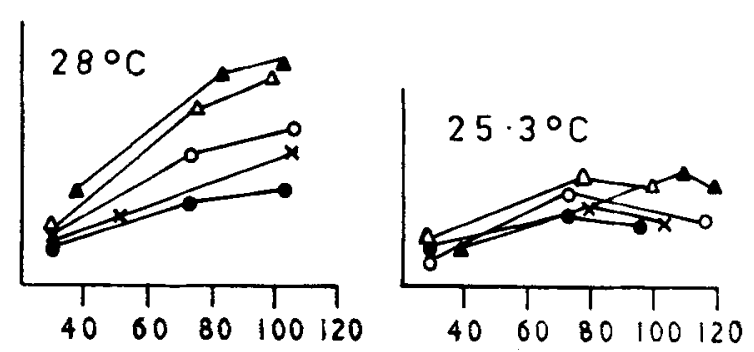

$\mathrm{PaCO}_{2}(\mathrm{~mm} \cdot \mathrm{Hg}$.

Figure 2 


\section{CHANGES IN VENTILATORY RESPONSES}

TO HYPERCAPNIA DURING REWARMING
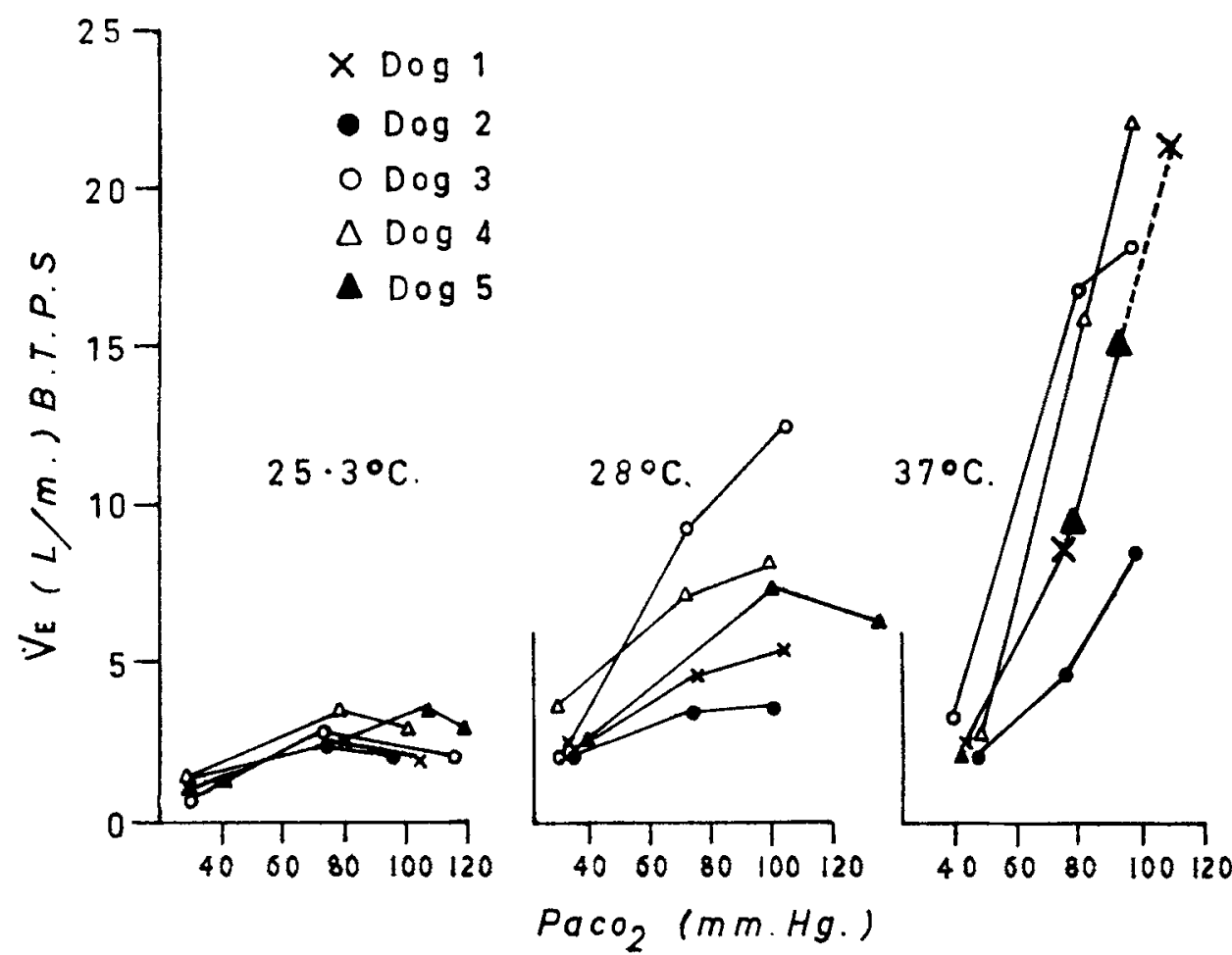

Figure 3

and $25.3^{\circ} \mathrm{C}$; resting $\mathrm{Paco}_{2}$ fell from $39.9 \mathrm{~mm}$ of mercury at $37^{\circ} \mathrm{C}$ to $30.8 \mathrm{~mm}$ of mercury and $31.2 \mathrm{~mm}$ mercury at $28^{\circ} \mathrm{C}$ and $25.3^{\circ} \mathrm{C}$ respectively. Arterial pH rose during cooling from 7.335 at $37^{\circ} \mathrm{C}$ to values between $7.41-7.42$ at lower temperatures and fell to 7.33 on rewarming to $37^{\circ} \mathrm{C}$. The mean base excess was maintained between -3.3 and -4.6 . The mean slope of the ventilatory response curve to $\mathrm{CO}_{2}$ also decreased progressively during cooling (from 0.23 litres per minute per $\mathrm{mm}$ of mercury at $37^{\circ} \mathrm{C}$; to 0.045 litres per minute per mm of mercury at $28^{\circ} \mathrm{C}$ and to 0.022 litres per minute per mm of mercury at $25.3^{\circ} \mathrm{C}$ and rose again after rewarming to 0.24 litres per minute per mm of mercury at $37^{\circ} \mathrm{C}$. The depression of ventilatory response is well demonstrated in Figures 2 and 3.

Mean resting ventilation fell to 57 per cent at $28^{\circ} \mathrm{C}$, and to 43 per cent at $25.3^{\circ} \mathrm{C}$ of the normothermic ventilation, while resting $\mathrm{PaCO}_{2}$ declined simultaneously by 22 per cent.

\section{Discussion}

There is a progressive reduction in ventilatory responsiveness to carbon dioxide as body temperature is lowered. This is reversible by rewarming. 


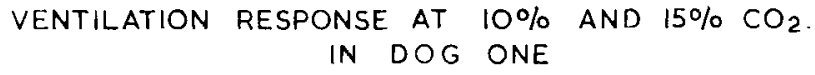

\begin{tabular}{|c|c|c|c|c|c|}
\hline \multirow{7}{*}{$\begin{array}{l}0 \\
z \\
\\
0 \\
0 \\
0 \\
u\end{array}$} & \multirow{3}{*}{$37^{\circ} \mathrm{C}$} & \multirow[b]{2}{*}{ VE } & $\% \mathrm{CO}_{2}$ & $10 \%$ & $15 \%$ \\
\hline & & & 2.9 & 10.1 & 26.2 \\
\hline & & $\mathrm{PaCO}_{2}$ & 39 & 69 & 110 \\
\hline & \multirow{2}{*}{$28^{\circ} \mathrm{C}$} & VE & 1.2 & 2.1 & 4.0 \\
\hline & & $\mathrm{PaCO}_{2}$ & 29 & 51 & 105 \\
\hline & \multirow{2}{*}{$25.3^{\circ} \mathrm{C}$} & $V E$ & 1.3 & 2.5 & 1.4 \\
\hline & & $\mathrm{PaCO}_{2}$ & 29 & 79 & 103 \\
\hline \multirow{6}{*}{ 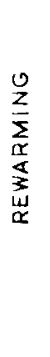 } & \multirow{2}{*}{$25.3^{\circ} \mathrm{C}$} & VE & 1.3 & 2.5 & 2.0 \\
\hline & & $\mathrm{PaCO}_{2}$ & 29. & 79 & 103 \\
\hline & \multirow{2}{*}{$28^{\circ} \mathrm{C}$} & $\dot{V} E$ & 2.1 & 4.6 & 5.4 \\
\hline & & $\mathrm{PaCO}_{2}$ & 30.5 & 72 & 103 \\
\hline & \multirow{2}{*}{$37^{\circ} \mathrm{C}$} & $\dot{V} E$ & 2.6 & 8.6 & 21.4 \\
\hline & & $\mathrm{PaCO}_{2}$ & 41.5 & 76 & 112 \\
\hline
\end{tabular}

Table II a

Our findings (Tables IIa and IIb) agree generally with those of Salzano, ${ }^{2} \mathrm{Ta}-$ keshi, ${ }^{10}$ Regan and Eger, ${ }^{3}$ who observed diminished ventilatory responses to carbon dioxide at $28^{\circ} \mathrm{C}$. In the latter study, initial normothermic and subsequent hypothermic slope values were higher than those observed in the present study and probably reflect differences in anaesthetic techniques and agents. Our results differ from those of Cranston et al..$^{1}$ who could demonstrate in anaesthetized dogs no difference in response at $37.5^{\circ} \mathrm{C}$ and $26^{\circ} \mathrm{C}$. However, their animals were premedicated with morphine and initial slopes were low. Subsequent depression from hypothermia was perhaps, therefore, minimal and difficult to demonstrate.

We observed variable responses among the animals at isothermic levels. This may relate to differing anaesthetic depths attained in each animal.

The fall in mean resting ventilation observed at $28^{\circ} \mathrm{C}$ was found to be 57 per cent of the normothermic ventilation and agrees with Spurr and his co-workers, ${ }^{10}$ who reported approximately 55 per cent reduction for a similar fall of body temperature.

It should be noted that an enriched inspired oxygen concentration was used during this study. Thus, arterial oxygen tension $\mathrm{PaO}_{2}$ was kept above $250 \mathrm{~mm}$ of mercury at all temperature levels. This more or less eliminated the hypoxic respiratory drive from peripheral chemoreceptors, although Hornbein and his associates have demonstrated slight activity even at this level of $\mathrm{PaO}_{2} .{ }^{11}$ Moreover, this high $\mathrm{PaO}_{2}$ was perhaps partly responsible for the depressed slope of ventilatory response to $\mathrm{CO}_{2}$ observed. Evidence from Cunningham and his co-workers ${ }^{12}$ 


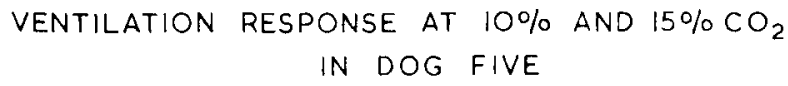

\begin{tabular}{|c|c|c|c|c|c|}
\hline \multirow{7}{*}{$\begin{array}{l}0 \\
\underline{z} \\
\vec{\jmath} \\
\stackrel{O}{O}\end{array}$} & \multirow{3}{*}{$37^{\circ} \mathrm{C}$} & \multirow[b]{2}{*}{$\dot{V} E$} & $\% \mathrm{CO}_{2}$ & $10 \%$ & $15 \%$ \\
\hline & & & 3.6 & 17.0 & 22.0 \\
\hline & & $\mathrm{PaCO}_{2}$ & 40 & 73 & 95 \\
\hline & \multirow{2}{*}{$28^{\circ} \mathrm{C}$} & $V_{E}$ & $2 \cdot 8$ & 6.4 & 6.6 \\
\hline & & $\mathrm{PaCO}_{2}$ & 37 & 84 & 103 \\
\hline & \multirow{2}{*}{$25.3^{\circ} \mathrm{C}$} & $V_{E}$ & 1.4 & 3.6 & 3.0 \\
\hline & & $\mathrm{PaCO}_{2}$ & 40 & 105 & 120 \\
\hline \multirow{6}{*}{ 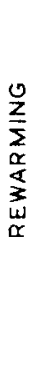 } & \multirow{2}{*}{$253^{\circ} \mathrm{C}$} & $V E$ & 1.4 & 3.6 & 3.0 \\
\hline & & $\mathrm{PaCO}_{2}$ & 40 & 105 & 120 \\
\hline & \multirow{2}{*}{$28^{\circ} \mathrm{C}$} & $V_{E}$ & 2.5 & 7.4 & 6.2 \\
\hline & & $\mathrm{PaCO}_{2}$ & 39 & 100 & 135 \\
\hline & \multirow{2}{*}{$37^{\circ} \mathrm{C}$} & $V_{E}$ & 22.0 & 9.0 & 15.0 \\
\hline & & $\mathrm{PoCO}_{2}$ & 42 & 80 & 95 \\
\hline
\end{tabular}

Table IIb

indicates that in awake man the slope may be depressed 10-20 per cent by elevating $\mathrm{PaO}_{2}$ from 100 to $350 \mathrm{~mm}$ of mercury, with little further change between 350 and $600 \mathrm{~mm}$ of mercury. However, this should not have contributed to the change in slopes observed under the conditions of this study since the $\mathrm{PaO}_{2}$ was kept above $250 \mathrm{~mm}$ of mercury at all temperature levels.

At resting ventilation, the $\mathrm{Paco}_{2}$ was maintained at a lower level during hypothermia, even though ventilatory responsiveness to $\mathrm{CO}_{2}$ challenge was markedly depressed.

The probable explanation for this disparity may be related to recent observations of Mitchell and his co-workers ${ }^{11}$ who have located paired areas sensitive to $\mathrm{H}^{+}$ion on the ventrolateral aspect of medulla of the cat. There is reason to believe that these areas are major sites of medullary chemo-sensitivity, and they have been termed intracranial chemoreceptors. Perfusing them with acidic solution of cerebrospinal fluid (CSF) caused hyperpnoca and with alkaline solution hypopnoea. Flooding these areas with cold solution of CSF depressed ventilation immediately. This suggests that the feeble ventilatory responsiveness to $\mathrm{CO}_{2}$ during hypothermia may result from cold depression of these intracranial chemoreceptors.

\section{SUMMARY}

Ventilatory responses of dogs to hypercarbia were measured during normothermia and at two levels of hypothermia. A technique of continuous spirometry 
was used to determine the minute ventilation. Minute ventilation and resting control $\mathrm{PaCO}_{2}$ fell with decreasing body temperatures. In addition, a progressive decrease was observed in ventilatory responsiveness to inhalation of increased carbon dioxide. In this study the resting ventilation maintained the $\mathrm{PaCO}_{2}$ lower during hypothermia even though ventilatory responsiveness to carbon dioxide challenge was markedly depressed.

\section{RÉSUMÉ}

Nous avons mesuré, durand la normothermie et sous deux différents niveaux d'hypothermie, les réponses ventilatoires à l'hypercarbie chez des chiens. Nous avons employé une technique de spirométrie continuelle pour déterminer la ventilation minute. A mesure que s'baissait la température corporelle, s'abaissaient également la ventilation minute et le contrôle de la $\mathrm{Paco}_{2}$ de repos. De plus, nous avons observé une diminution progressive de la réponse ventilatoire à l'inhalation d'un taux accru de dioxyde de carbone. Durant cette étude, la ventilation de repos a maintenu la $\mathrm{PaCO}_{2}$ plus basse durant l'hypothermie même si la réponse ventilatoire au dioxyde de carbone était fortement déprimée.

\section{ACKNOWLEDGMENTS}

The authors thank Professor Lucien E. Morris for his guidance and encouragement; Dr. V. M. Jones for chromatograph estimations of blood halothane; J. C. Kay for aid with the statistics, and Y. Gaiger for technical assistance.

Halothane was supplied by Ayerst Laboratories Limited.

This study was supported in part by a grant from the Medical Research Council of Canada (MA 3376).

\section{REFERENCES}

1. Cranston, W. I.; Pepper, M. C.; \& Ross, D. H. Carbon dioxide and control of respiration during hypothermia. J. Physiol., 127: 380 (1955).

2. Salzano, J., \& Hall, F. G. Effect of hypothermia on ventilatory response to carbon dioxide inhalation and carbon dioxide infusing in dogs. J. Appl, Physiol., 15: 397 (1960).

3. REGAN, M. J. \& EGER, E. J. Ventilatory responses to hypercapnia and hyponia at normothermia and moderate hypothermia during constant-depth halothane anaesthesia. Anesthesiology, 27: 624-633 (1966).

4. NunN, J. F. A new method of spirometry in routine anaesthesia. Brit. J. Anaesth., 28: 440-449 (1956).

5. Atrinson, R. S. Continuous flow spirometry in anaesthesia. Anaesthesia, 141: 231-239 (1959).

6. Comroe, J. H. JR. \& Kaffert, N. H. Measurement of gas volumes. In methods in medical research. J. H. Comroe Jr. Ed. Chicago: The Year Book ( 1950).

7. Rosenthal, T. B. Effect of temperature on the $\mathrm{pH}$ of blood and plasma in vitro. J. Biol. Chem., 173: 25 (1948).

8. Bradley, A. F.; Stupfel, M.; \& Severinghaus, J. W. Effect of temperature on $\mathrm{PaCO}_{2}$ and $\mathrm{PaO}_{2}$ of blood in vitro. J. Appl. Physiol., 9: 201 (1956).

9. TAKESH, U. Respiration in hypothermia, (2) $\mathrm{CO}_{2}$ sensitivity of respiratory system. J. Physiol. Soc. Japan, 26: 156 (1964).

10. Spurr, C. B.; Hutr, B. K.; \& Horvath, S. M. Responses of dogs to hypothermia. Amer. J. Physiol., 179: 139 (1954). 
11. Hornbin, T. F.; Grifro, Z. J.; \& Ross, A. Quantitation of chemoreceptor activity: Interrelation of hypoxia and Hypercapnia. J. Neurophysiol., 24: 561 (1961).

12. Cunningham, D. J. C.; Shaw, D. G.; Lahari, S.; \& Lloyd, B. B. The effect of maintained ammonium chloride acidosis on the relation between pulmonary ventilation and alveolar oxygen and carbon dioxide on man. Quart J. Exp. Physiol., 45: 323 (1961). 